\title{
Pengembangan Augmented Reality Sebagai Media dalam Meningkatkan Pemahaman Teks Bacaan
}

\author{
Ali Idrus ${ }^{1}$ \\ Andreo Yudherta ${ }^{2}$
}

\begin{abstract}
The main purpose of unitilize Augmented Reality is to visualize an object virtually in the real world thought visual and verbal(dual-coding). Dual-coding theory, is done to visualize reading text by using augmeted reality. Integration of text and marker on AR, had purposed by four scenarios, as 1) marker was partly made and placed beside text; 2) text directly as a marker; 3) text with frame as a marker; 4) marker as a background of text and made transparently. After the development of application and try outusing AR by using reading text three-demension object could be showed as a marker to trigger the object display.aplication could also track. The text by four diffrent scenerios of marker with the best result is by adding the frame in the text as a marker
\end{abstract}

Keyword:Augmented Reality, Dual Coding, marker, reading text

\begin{abstract}
Abstrak: Tujuan pemanfaatan Augmented Reality (AR) untuk memvisualisasikan benda secara virtual yang dimasukkan kedalam tampilan dunia nyata (dual-coding) melalui visual dan verbal. Teori dualcoding dilakukan untuk visualisasi teks bacaan dengan menggunakan AR. Integrasi teks dan marker pada AR, diusulkan empat skenario, yakni 1)Marker dibuat tersendiri dan diposisikan disamping teks bacaan;2)Teks dijadikan sebagai marker; 3)Teks diberi frame dan dijadikan sebagai marker; 4) Marker disisipkan ke dalam paragram dan dibuat sedikit transparans. Setelah dilakukan pengembangan aplikasi dan percobaan menggunakan teknologi AR dengan memanfaatkan teks bacaan dapat ditampilkan objek $3 D$ sebagai penanda (marker) untuk memicu tampilnya objek. Aplikasi juga mampu memindai teks bacaan dengan keempat skenario pemposisian marker, dengan hasil terbaik adalah dengan menambahkan frame pada teks sebagai marker.
\end{abstract}

Kata Kunci: Augmented Reality, Dual Coding, Marker, Teks bacaan

\section{PENDAHULUAN}

Fenomena umum rendahnya prestasi belajar para siswa sekolah menengah pertama terlihat antara lain; masih tingginya ketergantungan belajar pada guru dikelas; rendahnya usaha menambah wawasan dari berbagai sumber; mencontek tugas dan ulangan masih subur; belajar masih kebut semalam; rendah nya minat baca; sepi nya penggunaan media dan sumber belajar.
Fenomena diatas juga terlihat pada Pembelajaran Matematika di Sekolah Menengah Pertama yaitu banyak siswa yang mengalami kesulitan dalam belajar, merasa kurang menarik dan sulit untuk memahami bacaan buku teks sehingga berdampak pada rendah nya prestasi belajar.

Teknologi multimedia berkembang sangat cepat dalam dua dekade ini. Salah satu teknologi multimedia mulai populer saat ini adalah teknologi

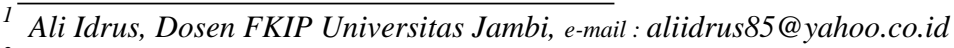

${ }^{2}$ Andreo Yudherta, Dosen Fakultas Teknik Universitas Jambi e-mail : a.yudertha@ gmail.com. 
Augmented Reality (AR). Perusahan raksasa Google, Microsof dan Intel beberapa tahun terakhir telah meluncurkan perangkat AR. Google Glass dan Holo Lens merupakan perangkat augmented yang dikembangakan oleh Google dan Microsoft.(http://googleglass//ok ).

Pada pemahaman suatu bacaan, Goodman (dalam Wayan, 2003:4) mengemukakan bahwa pembaca menggunakan sistem simbul (cue system) secara serentak yaitu graphophonic, syntactic, dan semantic. Melalui tiga sistem simbul ini pembaca meramalkan makna teks. Itu berarti dalam upaya pemahaman bacaan akan terjadi interaksi komunikasi antara pembaca dan teks yang dibaca. Tindakan membaca melibatkan unsur pembaca, teks, dan interaksi antara pembaca dan teks.

Pengembangan sebuah media pembelajaran yang melibatkan dua unsur secara bersamaan, yakni verbal dan nonverbal cukup jarang dilakukan. Penelitian ini mencoba untuk mengembangkan sebuah media yang melibatkan unsur verbal yang diwakili oleh teks bacaan dan media nonverbal berupa proyeksi tiga dimensi secara bersamaan dengan memanfaatkan teknologi AR.

Khairnar (2016:1) melakukan penelitian mengembangkan sebuah aplikasi AR (AR) dalam membantu pelanggan dalam menentukan posisi fornitur Rumah. Aplikasi berbasis AR ini menggunakan marker yang dapat dipindahkan kemana-mana dan diposisikan sesuai dengan keinginan pelanggan. Tiap marker akan merepresentasikan furnitur perlengkapan rumah yang berbeda-beda.

Pengembangan AR juga dilakukan oleh Mauro (2015:1). Mauro menggunakan teknologi AR dalam pembelajaran matematika. Mauro memanfaatkan AR untuk menyediakan kegiatan yang siswa dapat lakukan dirumah dan meningkatkan waktu yang dihabiskan bagi siswa untuk belajar dan mempraktekkan ilmu matematika. Teknologi AR yang digunakan berbeda-beda untuk menampilkan solusi dari masalah praktis dengan menggunakan berbagai media termasuk menggunakan video.

$$
\text { Selanjutnya Magdalena }
$$
mengembangkan sebuah aplikasi yang menggunakan AR dalam pendidikan. Aplikasi tersebut mengintegrasikan konten pendidikan geosains kedalam dunia nyata yang disebut Field Play. Field Play memiliki dua tujuan utama, yakni meningkatkan akses informasi sains yang berlimpah dalam linkungan sekitar dan mempromosikan pendidikan sains dalam skala yang besar.

Telah banyak penelitian yang dilakukan mengenai penerapan AR dalam dunia pendidikan. Peng Chen telah melakukan survey (2016:13) terhadap 55 penelitian yang dipublikasikan antara tahun 2011 dan 2016 mengenai state of the art dalam penelitian AR dalam dunia pendidikan. Survei tersebut menjelaskan mengenai kecenderungan dan visi kedepan serta peluang penelitian AR dalam dunia pendidikan.

Menurut Azuma (2007:2) AR merupakan variasi dari Virtual Environments (VE) atau sering disebut Virtual Reality (VR). AR memungkinkan pengguna melihat dunia nyata, dengan menambahkan objek virtual yang dikombinasikan secara real-tim

Azuma R T (2007:3) juga menyebutkan bahwa AR telah diaplikasikan dalam berbagai bidang, seperti dibidang medis yang digunakan untuk visualisasi dan pelatihan dalam operasi, 
memvisualisasikan objek dan lingkungan baik informasi publik atau privat, dibidang robotika, entertaimen, serta militer. Tujuan utama dari pemanfaatan AR ini adalah untuk memvisualisasikan benda secara virtual yang dimasukkan kedalam tampilan dunia nyata

Menurut Lee (dalam Andria 2013:227), AR sangat berpotensi dan menarik, menginspirasi, dan memotivasi pelajar untuk mengeksplorasi dan melakukan pengontrolan dari berbagai perspektif yang berbeda, yang sebelumnya tidak menjadi bahan pertimbangan dalam dunia pendidikan.

Jessnor (2016:42) melakukan penelitian dengan tujuan untuk mengeksplorasi penggunaan AR (AR) dikalangan siswa tingkat pendidikan tinggi. Di tengah cepatnya perubahan dalam teknologi, AR dianjurkan sebagai salah satu teknologi baru yang dapat menjadi pelopor dalam pembelajaran aktif dan pada saat yang sama dapat sebagai media inovasi dalam proses pembelajaran. Jessnor (2016:42) juga menyebutkan bahwa siswa menganggap AR sebagai suatu hal yang menarik, berguna dan sesuatu hal yang dapat digunakan sebagai media pembelajaran. Selain itu, teknologi AR dapat mendorong siswa untuk belajar secara mandiri.

Di bidang pendidikan Xiaolin (2016:77) mengusulkan sebuah model smart learning dalam mewujudkan usulan dari IBM. Smart Learning merupakan aktivitas yang mampu meningkatkan pengalaman belajar, meningkatkan konten yang berkelanjutan dan meningkatkan efisiensi dalam pembelajaran.

Jo (dalam Xiaolin 2016:79) menjelaskan bahwa ada beberapa hal inti dari smart learning seperti sensible, adaptable dan caring. Sensible mengacu pada teknologi pemposisian (seperti GPS, RFID, dan QRCode), sensor (seperti sensor suhu, kelembaban, karbon dioksida, dan pencahayaan) dan kuisioner yang digunakan untuk mendapatkan indikator lingkungan dan fitur pembelajaran dari peserta didik. Adaptable menggambarkan kondisi baik sumber pembelajaran dan aktivitas pembelajaran yang diharapkan oleh setiap individu peseta didik. Caring merupakan sikap dari pengajar dan peserta didik dalam membangun dan menjaga hubungan kepercaan dalam proses pembelajaran.

$$
\text { Huang (dalam Xiaolin 2016: 79) }
$$

memaparkan smart learning environment didefinisikan sebagai kondisi belajar atau ruang aktivitas dari fasilitas pembelajaran yang efektif dengan mempertimbangkan skenario, identifikasi hal yang dimiliki oleh pembelajar, penelusuran proses belajar, dan evaluasi hasil dari pembelajar. Pada smart learning environment, batas antara dunia nyata dan dunia virtual dieliminasi, dan dapat menyediakan siswa dukungan dan layananan yang baik. Gabungan komponen dari smart learning environment adalah perangkat cerdas dengan skenario pembelajaran yang dapat diidentifikasi, proses pembelajaran dapat ditelusuri, indikator dari lingkungan dilibatkan, serta fitur pembelajaran dapat diterima.

Atas dasar beberapa penjelasan di atas, sebagai bagian kecil dari perwujudan smart learning yang memanfaatkan teknologi digital, maka penelitian ini mencoba untuk mengintegrasikan AR dalam proses pembelajaran, dengan tujuan untuk meningkatkan pemahaman teks. Penggunaan dua masukkan dalam membaca yakni media verbal maupun nonverbal akan dirancang menggunakan teknologi AR. Penelitian 
dilakukan hanya sampai pada penerapan teks bacaan sebagai marker atau trigger dalam menampilkan objek 3D.

\section{Teori Dual-Coding}

Teori dual-coding (DCT) pertama kali dikemukakan oleh Allan Paivio pada tahun 1971. Paivio merupakan Profesor Psikologi di Universitas Western Ontario, Amerika Serikat. Paivio telah melakukan pengkajian terhadap siswa di Universitas MacGill pada tahun 1954 dan bekerjasama dengan Dr. Wallace Lambert dalam membangun pemprosesan dual coding. DCT mengasumsikan bahwa informasi dari yang masuk diproses dan disimpan oleh dua sistem yang saling terkoneksi dan membentuk kumpulan kode. Kumpulan kode tersebut, yakni kode visual dan kode verbal.

Berdasarkan teori Paivio (dalam Saguni 2006:152) tersebut, penerima informasi akan mendapatkan gambaran yang lebih baik jika kedua bentuk informasi (verbal dan visual) diterima, karena dengan demikian penerima informasi akan dapat mempertemukan informasi yang sama dalam bentuk yang berbeda dalam memori. Sementara integrated dual-code menunjukkan bahwa informasi visual dan informasi verbal dapat diterima dalam memori sama dengan hubungan antar informasi verbal dan informasi visual.

\section{Menurut Paivilio (2004:15) proses}

membaca dapat menjadi lebih baik ketika dijelaskan dengan contoh yang melibatkan pengkodean, pemahaman dan respon dalam membaca sebuah kalimat yang sederhana. Ini berarti bahwa kekayaan suatu kalimat mempengaruhi pembaca dalam memahami isi dari kalimat “tersebut.
Metode IT (integrated text) meliputi adanya penciptaan hubungan isi informasi yang diterima dalam bentuk verbal dan visual. Metode ST (separated text) meliputi hubungan yang terciptakan oleh penerima informasi hanya berbentuk representational connection atau sebatas penerimaannya, tidak sampai pada isinya. Dengan demikiant teks dan gambar secara dekat (IT) memberi hasil yang lebih baik dibandingkan dengan teks dan gambar secara terpisah (ST), kedua metode (IT dan ST) menimbulkan adanya hubungan penerimaan yaitu penggambaran secara mental dari isi informasi visual dan penggambaran secara mental dari isi informasi verbal. Maka teks dan gambar secara dekat hasilnya lebih baik dibandingkan dengan teks dan gambar secara terpisah.

Azuma R.T mendefinisikan AR sebagai penggabungan benda-benda nyata dan maya di lingkungan nyata, berjalan secara interaktif dalam waktu nyata, dan terdapat integrasi antarbenda dalam tiga dimensi, yaitu benda maya terintegrasi dalam dunia nyata. Penggabungan benda nyata dan maya dimungkinkan dengan teknologi tampilan yang sesuai, interaktivitas dimungkinkan melalui perangkat-perangkat input tertentu, dan integrasi yang baik memerlukan penjejakan yang efektif.

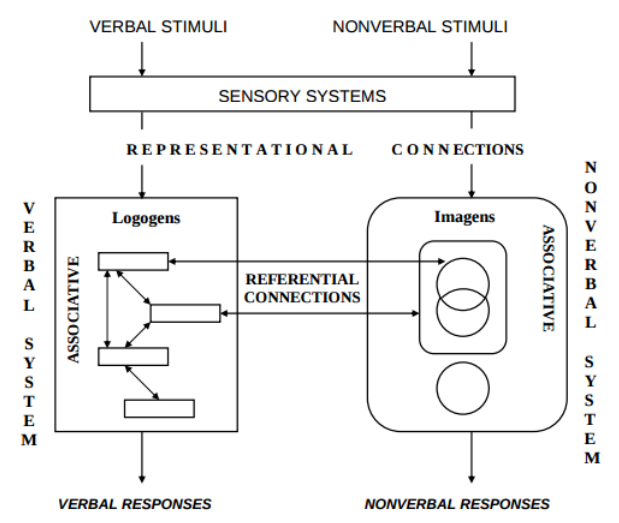

Gambar 1. Model umum DCT 
Pada teknologi AR terdapat istilah marker. Marker merupakan wadah untuk menampilkan objek 3D yang akan dimunculkan. Ada beberapa jenis marker yang sudah berkembang hingga saat ini seperti Marker Based Tracking dan Markerless.

Marker Based Tracking dan Marker Based Tracking merupakan ilustrasi hitam dan putih persegi dengan batas hitam tebal dan latar belakang putih. Komputer akan mengenali posisi dan orientasi marker dan menciptakan dunia virtual 3D yaitu titik $(0,0,0)$ dan 3 sumbu yaitu X,Y,Z. Marker Based Tracking ini sudah lama dikembangkan sejak 1980-an dan pada awal 1990-an mulai dikembangkan untuk penggunaan AR.

Markerless salah satu metode AR yang saat ini sedang berkembang adalah metode "Markerless $A R$ ", dengan metode ini pengguna tidak perlu lagi menggunakan sebuah marker untuk menampilkan elemen-elemen digital. Seperti yang saat ini dikembangkan oleh perusahaan $\mathrm{AR}$ terbesar di dunia Total Immersion, mereka telah membuat berbagai macam teknik Markerless Tracking sebagai teknologi andalan mereka, seperti Face Tracking, 3D Object Tracking, dan Motion Tracking.

Menurut penjelasan Haller, Billinghurst, dan Thomas (dalam Aditia 2016:22), riset AR bertujuan untuk mengembangkan teknologi yang memperbolehkan penggabungan secara real-time terhadap konten digital yang dibuat oleh komputer dengan dunia nyata. AR memperbolehkan pengguna melihat objek virtual tiga dimensi yang diproyeksikan terhadap dunia nyata.

Saphiro dan Stockman (dalam Aditia 2016:2) menyatakan pembuatan sistem AR membutuhkan beberapa hal yakni (1) Model 3D dari objek untuk digabungkan dengan dunia nyata; (2) Korespondensi antara dunia nyata dengan model 3D melalui kalibrasi; (3) Tracking digunakan menentukan sudut pandangan pengguna terhadap dunia nyata; (4) Real-Time Display yang digabungkan dengan citra asli dan juga grafik komputer yang dibuat berdasarkan model; (5) Waktu respon terhadap gerakan dan akurasi antara gambar dan grafik sangat mempengaruhi keefektifan sistem.

Android adalah sistem operasi dengan sumber terbuka, dan Google merilis kodenya di bawah Lisensi Apache. Kode dengan sumber terbuka dan lisensi perizinan pada Android memungkinkan perangkat lunak untuk dimodifikasi secara bebas dan didistribusikan oleh para pembuat perangkat, operator nirkabel, dan pengembang aplikasi. Selain itu, Android memiliki sejumlah besar komunitas pengembang aplikasiyang memperluas fungsionalitas perangkat, umumnya ditulis dalam versi kustomisasi bahasa pemrograman Java.

Vuforia merupakan software development kid yang digunakan untuk mengembangkan aplikasi AR. Ada beberapa paket dari vuforia dari yang gratis dan yang berbayar. Vuforia mendukung beberapa aplikasi pengembangan AR, seperti sdk untuk android dan mendukung aplikasi tiga dimensi Unity3D

Masalah dalam penelitian ini adalah bagaimana mengembangkan media pembelajaran berbasis pada teknologi AR yang memanfaatkan teks bacaan sebagai marker. Tujuan yang ingin dicapai adalah menampilkan teks bacaan dan visualisasi tiga dimensi secara bersamaan dengan 
maksud untuk meningkatkan pemahaman pembaca terhadap bacaan.

\section{METODE}

Pada penelitin ini digunakan metode penelitian pengembangan dengan mengadaptasikan model Borg dan Gall, yang menyebutkan, "Educational research and development ( $R$ and $D)$ is a process used to develop and validate educational product. The step of this process are usually referred to as the $R \& D$ cycle, which consists of studying reseach finding partinent to the product to be developed, developing the product based on the finding, field testing it in the setting where it used eventually, and revising it to correct the deficiencies found in the field testing stage. In indicate that product meets its behaviorally defined Objectives".(dalam Wuryani 2015:86). Tujuan utama prosedur penelitian pengembangan menurut Bord and Gall pada dasarnya adalah mengembangkan produk; (2) menguji keefektifan produk dalam mencapai tujuan.

Tahapan yang dilakukan dalam penelitian ini mengadaptasikan model dari Borg dan Gall dengan menggabungkan beberapa tahap menjadi satu tahapan tanpa mengurangi inti dari model Borg dan Gall. Penyederhanaan dikarenakan keterbatasan waktu.

Pada tahap awal dilakukan analisa terhadap materi yang akan dijadikan sampel penerapan aplikasi AR. Materi-materi ini didapat dari buku pelajaran yang telah ada. Kemudian dianalisa bagian mana saja yang menjadi inti pokok dari mata pelajaran. Inti-inti pokok pelajaran tersebutlah yang menjadi sasaran pengembangan aplikasi AR. Analisa dilakukan dengan mempelajari paragraf dan kalimat yang memungkinkan untuk divisualisasikan dengan aplikasi AR.

$$
\text { Penelitian dilakukan dengan }
$$

mengembangkan aplikasi AR dan menjadikan teks bacaan sebagai marker. Pada tahap awal dilakukan perancangan skenario penggunaan aplikasi dalam proses pembelajaran. Pada tahap ini juga dilakukan analisa teks seperti apa yang akan divisualisasikan dengan menggunakan aplikasi.

Tahap kedua yakni mengembangkan prototipe dari aplikasi AR dan marker. Aplikasi dikembangkan dengan menggunakan vuforia dan smartphone android. Vuforia merupakan perangkat yang dapat digunakan untuk mengmbangkan teknologi AR.

Pengembangan aplikasi dilakukan dengan beberapa tahap seperti berikut ini, yakni (1) analisis kebutuhan sistem; (2) desain; (3) implementasi ; (4) pengujian.

Tujuan dari tahap analisa kebutuhan sistem ini adalah menganalisa apa saja kemampuan yang akan dipenuhi oleh sistem. Hasil dari tahap ini didapat dari hasil tahap analisis dan media pada tahapan penelitian, yang nanti diterapkan pada aplikasi AR. Selain itu, pada tahap ini akan ditemukan hal-hal apa saja yang dibutuhkan untuk pengembangan aplikasi AR.

Pada tahap desain, dirancang skenario penggunaan aplikasi. Perancangan berbasis skenario juga pernah diimplementasikan dalam perancangan aplikasi dalam domain yang berbeda (Yudertha, 2014:146). Skenario penggunaan aplikasi bertujuan agar korelasi antara model dan teori yang digunakan serta penerapan aplikasi dalam perancangan dapat terlihat. Selain itu juga didesain pemposisian marker dalam penggunaan aplikasi AR yang 
dirancang dengan empat skenario pemposisian marker.

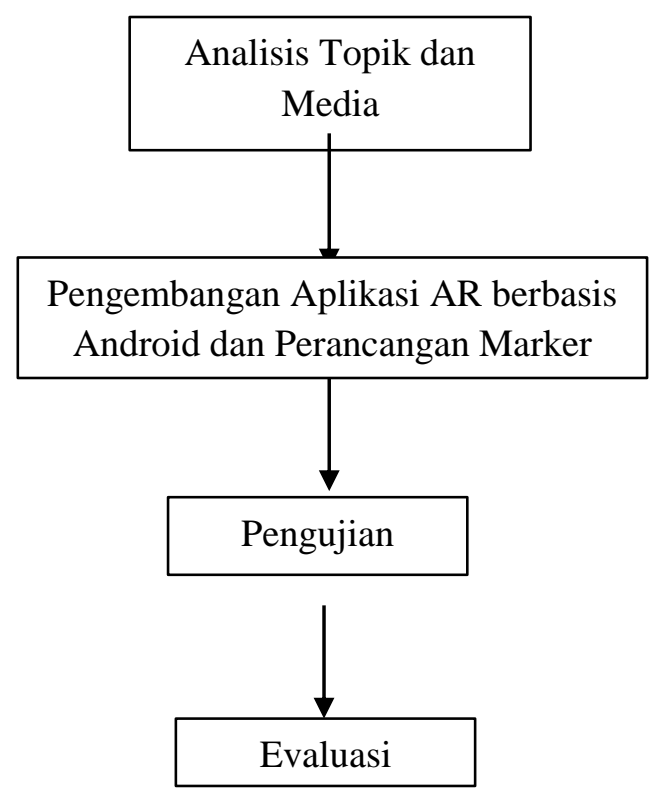

Gambar 2. Alur Penelitian

Adapun skenario pembuatan marker adalah sebagai berikut, yakni (1) Marker dibuat tersendiri dan diposisikan disamping teks; (2) Teks dijadikan sebagai marker; (3)Teks diberi frame dan dijadikan sebagai marker; (4) Marker disisipkan kedalam paragram dan dibuat sedikit transparans.

Pada tahap implementasi dilakukan implementasi dari keseluruhan model rancangan yang telah dibuat, dari sisi aplikasi dan dari sisi marker. Implementasi marker dilakukan dengan menyisipkan marker-marker tambahan ke dalam buku referensi dengan keempat skenario pemposisian marker.

Tahap selanjutnya dilakukan pengujian keempat skenario pemposisian marker. Pengujian dilakukan dengan mengukur jarak munculnya gambar serta sudut saat aplikasi dijalankan. Pengukuran ini dilakukan untuk menguji keefektifan keempat skenario pemposisian marker dalam memunculkan gambar 3D.

Tahap evaluasi dilakukan dengan mengevaluasi hasil pengujian keempat skenario pemposisian marker. Evaluasi dilakukan berdasarkan atas hasil pengujian. Pada tahap ini ditentukan pemposisian marker mana yang paling tepat digunakan dalam memvisualisasikan bacaan untuk membantu pemahaman terhadap bacaan.

\section{Hasil dan Pembahasan}

Penelitian ini berfokus pada tahap pengembangan prototype aplikasi yang berbasis pada teknologi AR yang menggunakan smartphone sebagai media untuk mendeteksi marker dan menampilkan gambar 3D. Aplikasi ini akan digunakan siswa sebagai alat bantu dalam proses belajar secara mandiri dengan tetap menggunakan buku bacaan sebagai dasar sumber utama dalam proses pembelajaran.

Buku pelajaran yang digunakan oleh siswa dapat dijadikan marker untuk memicu tampilnya gambar 3D yang sesuai dengan bacaan tesebut. Hal ini bertujuan untuk mempermudah siswa dalam memahami bacaan dalam buku pelajaran, dimana gambar yang akan ditampilkan sesuai dengan inti dari bacaan.

Aplikasi telah dapat mendeteksi marker sesuai dengan data marker yang telah didaftarkan pada Aplikasi. Kerika smartphone mendeteksi tulisan yang menjadi marker, aplikasi dapat menampilkan objek tiga dimensi

Aplikasi AR ini dirancang sebagai media pendukung dari buku bacaan yang digunakan. Buku yang digunakan akan sedikit dimodifikasi untuk menambahkan marker sehingga dapat menampilkan visualisasi dari bacaan. 
Pada sisi aplikasi, setelah aplikasi dijalankan dan kamera diarahkan ke bacaan, aplikasi akan mendeteksi marker yang terdapat pada bacaan. Marker-marker tersebut merupakan marker yang diletakkan pada setiap bacaan yang akan divisualisasikan. Marker merupakan pola-pola yang digunakan sebagai patokan bagi aplikasi untuk menampilkan visualisasi tiga dimensi (3D).

Pada saat marker yang berupa pola tertentu dideteksi, secara otomatis aplikasi akan mencocokan pola dengan visualisasi tiga dimensi yang tersimpan pada aplikasi. Pada aplikasi terdapat pasangan antara pola marker dan visualisasi tiga dimensi (3D), Visualisasi tiga dimensi ditampilkan sesuai dengan marker yang sesuai. Pencocokan pola dengan objek tiga dimensi (3D) dilakukan secara programmatical.

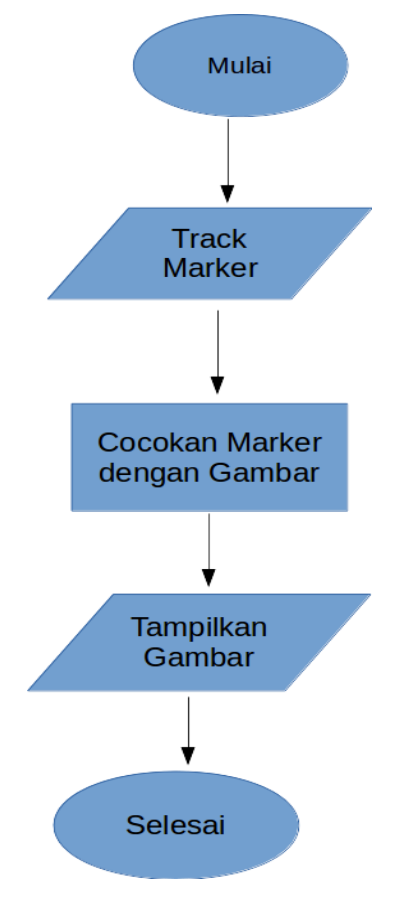

Gambar 3 Diagram Alur Aplikasi

Soal yang divisualisasikan dibuatkan markernya. Marker merupakan gambar unik yang memiliki fitur tersendiri untuk dapat dipindai oleh aplikasi. Setiap marker memiliki fitur. Fitur adalah karakteristik dari sebuah marker. Pada vuforia fitur dari sebuah gambar yang akan dijadikan marker dapat diukur. Adapun skenario pemposisian marker adalah sebagai berikut.

1. Marker dibuat tersendiri dan diposisikan disamping teks.

Marker dibuat tersendiri yang berupa $Q R$ Code dan kemudian diposisikan disamping teks, QRCode dan teks inilah yang dijadikan sebagai marker pada skenario ini. Tujuan dari penggunaan $Q R$ Code ini adalah untuk menambah fitur dari marker yang berupa teks dan $Q R$ Code. $Q R$ Code yang berbedabeda dikombinasikan dengan teks bacaan untuk menjadi marker. Pertimbangan penggunaan $Q R$ Code ini adalah untuk menghindari kemiripan fitur teks satu dengan teks yang lain ketika dijadikan marker.

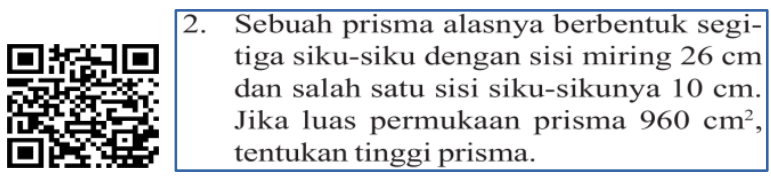

Gambar 4 Marker diposisikan disamping Teks

2. Teks dijadikan sebagai marker.

Skenario kedua adalah dengan menjadikan teks langsung sebagai marker. Penanda tambahan tidak digunakan pada skenario ini. Hal ini dilakukan untuk menguji apakah tanpa penanda tambahan aplikasi masih dapat memindai teks seebagai marker.
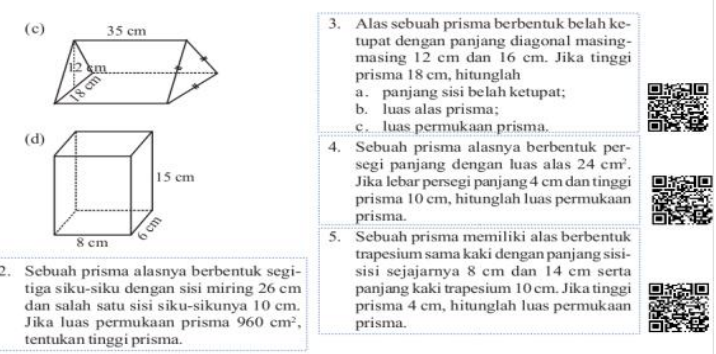

Gambar 5 Integrasi Marker disamping teks 
3. Teks diberi frame dan dijadikan sebagai marker Skenario ketiga adalah dengan memodifikasi teks. Teks diberikan frame unik dan kemudian digunakan sebagai marker. Penambahan frame ini bertujuan untuk menambah fitur tambahan dalam teks ketika menjadi marker. Frame dibuat sedemikian hingga dan diposisikan disamping teks bacaan.

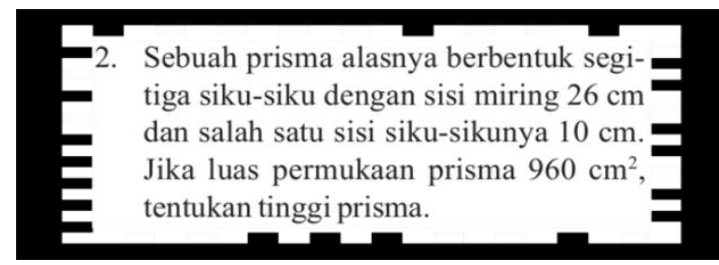

Gambar 6 Teks dikombinasikan dengan frame sebagai marker.

4. Teks diberi gambar latar

Skenario ke empat adalah dengan memasukkan marker sebagai backgorund dari teks yang sedikit dibuat transparans. Tujuan dari penambahan gambar latar pada teks adalah untuk menambahkan fitur pada teks bacaan ketika menjadi marker

\section{Sebuah prisma alasnya berbentuk segi- tiga siku-siku dengan sisi miring $26 \mathrm{~cm}$ dan salah satu sisi siku-sikunya $10 \mathrm{~cm}$. Jika luas permukaan prisma $960 \mathrm{~cm}^{2}$, tentukan tinggi prisına.}

Gambar 7 Teks diberi gambar latar sebagai marker

$$
\text { Pengembangan aplikasi menggunakan }
$$

vuforia. Vuforia merupakan application library yang cukup umum digunakan dalam mengembangkan aplikasi AR. Vuforia menyediakan cukup lengkap perangkat dalam pengembangan aplikasi AR, baik dari segi pemograman sampai ke pembuatan marker.

$$
\text { Marker pada aplikasi AR yang }
$$
menggunakan Vuforia harus dikonversi terlebih dahulu kedalam ekstensi .dat dan .xml. Kedua file tersebut digunakan sebagai dasar pada aplikasi untuk mengidentifikasi marker yang dipindai oleh kamera smartphone. Konversi marker dapat dilkakukan di situs vuforia, yakni https://developer.vuforia.com/ targetmanager/ project/device/TargetListing.

Marker yang telah dirancang diupload dengan ekstensi .jpg atau .png ( 8 bit gray scale atau 24 bit RGB) dengan maksimal ukuran 2MB. Konversi file marker dapat dilakukan secara komprehensif. Hasil dari konversi berupa file dataset dari marker.

Hasil dari konvesi marker ke .dat dan .xml dapat didownload. File .dat dan .xml digunakan dalam pemograman sebagai dataset untuk mencocokan pindaian kamera smartphone dengan marker target yang telah dirancang sebelumnya.Informasi rating pada hasil upload menunjukkan tingkat sensitifitas dari marker agar dapat dipindai oleh aplikasi.

File dat dan .xml hasil dari konversi digunakan sebagai file pendukung dalam aplikasi secara programmatical. Ketika aplikasi memindai target dengan menggunakan kamera, program akan mencocokan hasil pindaian dengan dataset dari file .dat dan .xml. Setelah terdapat kecocokan hasil pindaian dengan dataset maka aplikasi akan menambahkan gambar 3D kedalam layar kamera dan diposisikan sesuai dengan posisi marker yang dipindai.

Setelah dataset diimplementasikan pada aplikasi, maka dilakukan pengujian terhadap aplikasi dengan beberapa parameter, yakni sudut pemindaian marker dan jarak antara marker dan kamera smartphone. Pengujian dilakukan dengan smartphone dengan merk lenovo s820 dengan spesifikasi sebagai berikut. 
Dimensi: $139.5 \times 69.7 \times 9 \mathrm{~mm}(5.49 \times 2.74 \times 0.35$ in); Berat: 143 g (5.04 oz);Tipe:IPS LCD capacitive touchscreen, $16 \mathrm{M}$ colors

Ukuran : 4.7 inci ( $62.6 \%$ screen-to-body ratio); Resolusi: 720 x 1280 pixels ( 312 ppi pixel density); OS : Android OS, v4.2 (Jelly Bean); Chipset : Mediatek MT6589;

CPU: Quad-core 1.2 GHz Cortex-A7; GPU: PowerVR SGX544; Kamera: 12 MP, autofocus, LED flash;

Hasil untuk skenario pertama yakni marker unik diposisikan di samping teks, yakni (1) Jarak minimal dalam pengujian smartphone dapat menampilkan gambar adalah pada jarak $5 \mathrm{~cm}$ dengan persentase $5 \%$ dari 40 kali percobaan; (2) Jarak minimal yang paling banyak memunculkan objek adalah pada jarak $7 \mathrm{~cm}$ dengan persentase dari 40 kali percobaan sebesar 30 \%; (3) Pada sudut 90 derajat jarak paling kecil dan rata-rata jarak minimal untuk memunculkan objek adalah secara berturut-turut sebesar $5 \mathrm{~cm}$ dan $7.95 \mathrm{~cm}$; (4) Pada sudut 40 derajat jarak paling kecil dan rata-rata jarak minimal untuk memunculkan objek adalah sebesar $6 \mathrm{~cm}$ dan $8.05 \mathrm{~cm}$.

Hasil untuk skenario kedua yakni teks dijadikan marker, yakni (1) Jarak minimal dalam pengujian smartphone dapat menampilkan gambar adalah pada jarak $5 \mathrm{~cm}$ dengan persentase kemunculkan dalam 40 kali percobaan sebesar 5\%; (2) Jarak minimal yang paling banyak memunculkan objek adalah pada jarak $9 \mathrm{~cm}$ dengan persentase dari 40 kali percobaan sebesar 22,5\%; (3) Pada sudut 90 derajat jarak paling kecil dan ratarata jarak minimal untuk memunculkan objek adalah berturut-turut sebesar $5 \mathrm{~cm}$ dan $7.1 \mathrm{~cm}$; (4) Pada sudut 40 derajat jarak paling kecil dan rata- rata jarak minimal untuk memunculkan objek adalah sebesar $9 \mathrm{~cm}$ dan $10 \mathrm{~cm}$; (5) Pada sudut 40 derajat terdapat tiga kali kegagalan dalam memunculkan gambar dengan presentase $25 \%$.

Hasil untuk skenario ketiga yakni teks diberi frame dan dijadikan sebagai marker, yakni (1) Jarak minimal dalam pengujian smartphone dapat menampilkan gambar adalah pada jarak $6 \mathrm{~cm}$, dengan persentase kemunculkan dalam 40 kali percobaan sebesar 15\%; (2) Jarak minimal yang paling banyak memunculkan objek adalah pada jarak $7 \mathrm{~cm}$ dengan persentase dari 40 kali percobaan sebesar $55 \%$; (3) Pada sudut 90 derajat jarak paling kecil dan rata-rata jarak minimal untuk memunculkan objek adalah berturut-turut sebesar 7 cm dan $7.65 \mathrm{~cm}$; (4) Pada sudut 40 derajat jarak paling kecil dan rata-rata jarak minimal untuk memunculkan objek adalah sebesar $6 \mathrm{~cm}$ dan 6.9 $\mathrm{cm}$.

Hasil untuk skenario keempat yakni marker unik diposisikan sebagai latarbelakang teks, yakni (1) Jarak minimal dalam pengujian smartphone dapat menampilkan gambar adalah pada jarak $7 \mathrm{~cm}$ dengan persentase kemunculkan dalam 40 kali percobaan sebesar 2.5\%; (2) Jarak minimal yang paling banyak memunculkan objek adalah pada jarak $8 \mathrm{~cm}$ dengan persentase dari 40 kali percobaan sebesar $12.5 \%$; (3) Pada sudut 90 derajat jarak paling kecil dan rata-rata jarak minimal untuk memunculkan objek adalah berturut-turut sebesar 7 $\mathrm{cm}$ dan $9.7 \mathrm{~cm}$. (4) Pada sudut 40 derajat rata-rata terjadi kegagalan dalam memunculkan objek

Tabel 1 menunjukkan hasil pengujian terhadap keempat skenario pembuatan marker. Pengujian terhadap teks yang diberi marker dilakukan dengan mengukur jarak minimal 
smartphone dengan teks hingga dapat menampilkan objek tigadimensi. Selain itu juga diukur dengan dua sudut yang berbeda yakni pada sudut 90 derajat dan 40 derajat.

Pengukuran dilakukan dengan mengarahkan kamera smartphone ke tulisan yang menjadi marker. Kamera smartphone diarahkan ke marker dari jarak yang paling kecil kemudian sedikit-demi sedikit dijauhkan hingga menampilkan gambar tiga dimensi pada smartphone. Pada saat gambar mulai tampil itulah sebagai ukuran jarak tampilnya gambar.

Jarak terjauh tampilnya gambar tiga dimensi pada smarthone tidak dihitung. Karena pada jarak yang cukup jauh gambar tiga dimensi pada kamera akan terlihat kecil. Selain itu aplikasi AR ini cukup mampu memindai pada jarak yang cukup jauh, asal teks masih dapat dibaca pada jarak tersebut.

Pada tabel 1 pembanding terlihat bahwa penempatan marker pada skenario ketiga dan skenario pertama, tanpa kegagalan dalam menampilkan objek pada smartphone. Penggunaan marker tambahan pada teks berupa frame atau pun gambar kode QR akan menambahkan fitur unik bagi aplikasi untuk membedakan teks satu dengan yang lain dalam memindai teks.

Pada skenario ketiga jarak minimal yang paling sering memunculkan objek adalah pada jarak $7 \mathrm{~cm}$. Nilai tersebut merupakan nilai yang paling baik dengan persentase 55\% dari 40 kali percobaan. dibandingkan dengan skenario lain skenario ketiga lebih efektif sebagai marker pada teks untuk memunculkan objek tiga dimensi.

Skenario keempat merupakan skenario yang paling tidak efektif dengan jarak kemunculkan objek paling banyak adalah sebesar $8 \mathrm{~cm}$ dengan persentase kemunculan sebesar $12.5 \%$. Kegagalan kemunculan objek sebanyak 19 kali percobaan pada sudut 40 derajat dengan persentase sebesar $47.5 \%$ kegagalan dari 40 kali percobaan dan 95\% dari 20 kali percobaan pada sudut 40 derajat.

Tabel 1 Hasil pengujian penempatan marker.

\begin{tabular}{|l|c|c|c|c|}
\hline \multicolumn{1}{|c|}{ Kemunculan Objek } & Skenario 1 & Skenario 2 & Skenario 3 & Skenario 4 \\
\hline \hline Jarak minimal terhadap Teks $(\mathrm{cm})$ & 5 & 5 & 6 & 7 \\
\hline Nilai Modus jarak terhadap teks $(\mathrm{cm})$ & $7(50 \%)$ & $9(22.5 \%)$ & $7(55 \%)$ & $8(12.5 \%)$ \\
\hline Jarak minimal 90 derajat $(\mathrm{cm})$ & 5 & 5 & 7 & 7 \\
\hline Jarak rata-rata 90 derajat $(\mathrm{cm})$ & 7.95 & 7.1 & 7.65 & 9.7 \\
\hline Jarak minimal 40 derajat $(\mathrm{cm})$ & 6 & 9 & 6 & - \\
\hline Jarak rata-rata 40 derajat $(\mathrm{cm})$ & 8.05 & 10 & 6.9 & - \\
\hline Gagal & - & 5 percobaan & - & 19 percobaan \\
\hline \hline
\end{tabular}

Pada sudut pandang estetika dan kemudahan dalam penempatan marker pada teks, penempatan marker tambahan (tidak hanya teks sebagai marker) sangat mengurangi naturalisasi dari teks. Pada hasil percobaan skenario kedua, tidaklah terlalu buruk untuk memposisikan teks langsung 
sebagai marker tanpa menggunakan marker tambahan.

Pada hasil percobaan ketidak berhasilkan untuk menampilkan objek pada skenario ketiga adalah pada sudut 45 derajat sebanyak 5 kali kegagalan. Namun, pada sudut 90 derajat keseluruhan percobaan berhasil menampilkan objek dengan jarak paling banyak adalah $9 \mathrm{~cm}$ dengan persentase 22.5 persen dari 40 kali percobaan.

Pada skenario keempat, yakni marker dijadikan latar belakang teks tidak direkomendasikan untuk digunakan. Mengacu dari percobaan dengan sudut 40 derajat, hampir keseluruhan percobaan gagal. Pada sudut 40 derajat fitur dari marker sangat sulit untuk dapat dipindai oleh marker. Selain itu, penggunaan gambar latar pada teks juga akan mengurangi kejelasan teks untuk dibaca oleh pembaca.

Pada skenario pertama dengan memasukkan marker disamping teks, memunculkan hasil yang cukup baik. Hanya saja sukup sulit untuk memposisikan marker tambahan pada teks dengan ruang kosong kertas yang cukup sempit. Dibutuhkan ruang ynng cukup besar untuk teks jika ingin menggunakan skenario ini.

Pada penelitian ini belum sampai pada perancangan objek 3D yang sesuai dengan isi teks dan penerapan pada proses belajar mengajar. Penelitian ini baru berfokus pada penempatan marker untuk aplikasi pada teks yang mengacu pada empat skenario penempatan marker, yakni marker tambahan diposisikan disamping teks, teks langsung menjadi marker tanpa marker tambahan, teks diberi frame sebagai marker tambahan, dan marker dijadikan latarbelakan teks.
Penggunaan marker yang diposisikan berdekatan dengan teks bacaan ditujukan untuk memudahkan pembaca dalam menerima informasi verbal dan nonverbal. Gambar yang terintegrasi dengan teks diharapkan meningkatkan kemampuan pembaca dalam memahami inti dari bacaan, setelah terlebih dahulu membaca teks tersebut tanpa gambar virtual. Selain itu, penggunaan gambar virtual yang ditampilkan diatas teks, akan membuat teks menjadi lebih menarik, sehingga komunikasi antara teks dan pembaca menjadi lebih interaktif.

Interaksi teks dan pembaca juga akan lebih interaktif dan informatif karena penggunaan AR ini. Penggunaan AR dapat menampilkan gambar tiga dimensi sehingga pembaca dapat melihat objek tiga dimensi dari tulisan teks dengan mengarahkan kamera dengan sudut berbeda-beda. Gambar tiga dimensi tersebut akan menampilkan hasil sesuai dengan sudut pandang dan arah kamera dari pengguna.

Menampilkan gambar tiga dimensi yang mencerminkan isi dari teks bacaan diatas teks bacaan itu sendiri dapat menghemat ruang pada kertas bacaan. Penyajian antar teks bacaan pada kertas tidak terganggu oleh gambar-gambar penjelasan dari teks, jika teks bacaan membutuhkan gambar pendukung untuk menjelaskan isi teks dengan memposisikan gambar dengan AR.

Kemampuan teknologi AR dalam menampilkan objek tiga dimensi dapat dimanfaatkan untuk menambah banyak informasi pada objek yang ditampilkan. Banyaknya informasi nonverbal yang berhubungan dengan informasi verbal yang didapatkan pada teks bacaan akan bantu pembaca dalam memahami dan menerima pesan dari teks bacaan. 
Berdasarkan analisa kebutuhan pembuatan aplikasi AR pada penelitian ini, maka proses-proses yang harus dapat dipenuhi oleh aplikasi,yakni

(1) Aplikasi harus mampu mendeteksi marker (penanda) sebagai pemicu munculnya visualisasi gambar; (2) Aplikasi harus mampu menampilkan gambar sesuai dengan bacaan; (3) Gambar-gambar yang divisualisasikan harus mampu menjelaskan inti dari bacaan; (4) Aplikasi harus user friendly dan mudah digunakan.

Kebutuhan-kebutuhan yang telah disebutkan harus terpenuhi oleh aplikasi yang dibangun agar dapat digunakan sebagai media pembelajaran.Adapun masukan yang dibutuhkan adalah berupa teks bacaan yang diambil dari buku pelajaran. Teks bacaan tersebut akan menjadi pedoman dalam perancangan objek yang akan ditampilkan oleh aplikasi. Keluaran yang dihasilkan oleh aplikasi adalah berupa gambar yang memvisualisasikan inti dari bacaan.

Sistem dirancang dengan sebaik mungkin, dengan memperhatikan kebutuhan dari siswa agar apat memanfaatkan aplikasi AR untuk membantu dalam pemahan bacaan, dengan tidak mengesampingkan sisi teknis dalam penggunaan aplikasi AR.

Mata pelajaran yang akan menjadi objek dari penelitian ini adalah matematika kelas sembilan mengenai topik bangun ruang. Topik ini diambil dengan pertimbangan sebagai berikut.

1.Siswa SMP merupakan masa-masa peralihan dari anak-anak dan remaja, sehingga dengan menerapkan hal-hal yang lebih menarik dalam pembelajaran seperi animasi dan objek-objek tiga dimensi lainya, siswa masih dapat tertarik terhadap hal-hal tersebut. Lain halnya jika digunakan pada siswa SMA, mereka sudah tidak terlalu tertarik dengan animasi dan objek-objek tiga dimensi (3D). 2.Topik bangun ruang dipilih karena untuk mempermudah peneliti dalam merancang objekobjek tiga dimensi yang akan ditampilkan.

3.Setelah dilihat dari buku yang digunakan, yakni buku matemateki BSE kelas 1 bacaan-bacaan pada materi bangun ruang lebih mudah untuk divisualisasikan.

Aplikasi AR ini dibangun dengan tujuan agar siswa dapat lebih mudah memahami soal-soal bacaan pada materi bangun ruang SMP kelas sembilan. Aplikasi AR ini dirancang sebagai media pendukung dari buku bacaan yang digunakan. Buku yang digunakan akan seditkit dimodifikasi untuk menambahkan marker sehingga dapat menampilkan visualisasi dari bacaan.

Bacaan-bacaan yang dibuat medianya dipilih dengan kriteria bacaan yang dapat divisualisasikan. Tujuan dari pemilihan ini adalah untuk membantu siswa dalam memvisualisasikan bacaan. Pada bacaan yang akan divisualisasikan akan disisipkan sebuah marker(penanda) sebagai pembangkit gambar aplikasi.

Hasil dari pengamatan terhadap buku yang digunakan, pemilihan bacaan yang akan divisualisasikan yakni bacaan-bacaan mengenai halhal berikut, yakni (1) Soal-soal bangun ruang; (2) Soal yang membutuhkan visualisasi untuk mempermudah siswa memvisualisasikan bacaan. (3) Soal-soal dengan angka-angka yang merujuk pada objek tertentu, dan visualisasi digunakan untuk menjelaskan angka tersebut merujuk pada objek apa.

Pada skenario penggunaan aplikasi, pembaca terlebih dahulu membaca teks tanpa 
menampilkan gambar tiga dimensi pada smartphone. Pembaca juga dapat menampilkan gambar tiga dimensi terlebih dahulu diatas teks bacaan, lalu membaca teks bacaan tanpa menampilkan gambar tiga dimensi pada smartphone.

Perancangan skenario penggunaan aplikasi ini bertujuan agar memberi gambaran penggunaan aplikasi agar dapat dimanfaatkan secara maksimal. Alur penggunaan aplikasi ini akan memberikan gambaran secara menyeluruh bagaimana aplikasi ini digunakan oleh siswa sehingga dapat diketahui bagaimana aplikasi ini akan diimplementasikan.

Skenario ini juga akan digunakan nantinya pada saat implementasi dilapangan ketika proses belajar mengajar dilaksanakan. Gambaran skenario ini merupakan rekomendasi dalam penggunaan aplikasi sesuai dengan tujuan dari pengguaan AR untuk meningkatkan proses pemahaman teks bacaan terutama dalam memahami bacaan soal dalam proses belajar mengajar.

Ada lima tahapan dalam penggunaan aplikasi ini dalam proses belajar mengajar.Pada tahap pertama, sebelum siswa menggunakan aplikasi, siswa mempelajari materi yang menjadi subjek pembelajaran. Materi diberikan layaknya kegiatan belajar mengajar seperti biasa. Tujuan dari pemberian materi ini adalah agar siswa telah memiliki informasi mengenai ruang lingkup dari bacaan. Materi diberikan oleh guru seperti biasa.

Setelah mempelajari materi mengenai subjek pelajaran, siswa mengerjakan soal-soal secara mandiri. Soal-soal pada buku inilah yang menjadi objek bacaan yang digunakan sebagai media penggunaan AR. Pada soal-soal inilah diambil soal-soal yang memungkinkan untuk divisualisasikan.

Penampilan gambar tiga dimensi pada smartphone dan proses pembacaan teks tanpa gambar dapat dilakukan secara berulang-ulang. Hal ini dilakukan agar koneksi atau hubungan antara informasi verbal dari bacaan dan informasi nonverbal dari gambar tiga dimensi pada smartphone yang ditampilkan ditas teks bacaan didapatkan oleh pembaca. Jika koneksi atau hubungan antara gambar yang ditampilkan di atas teks bacaan dapat ditemukan oleh pembaca, berdasarkan atas teori dual-coding, maka kondisi tersebut akan membantu pembaca dalam menangkap informasi yang disampaikan oleh teks bacaan, sehingga pesan yang disampaikan pada teks bacaan dapat diterima oleh pembaca.

Ada beberapa hal yang perlu di dipertimbangkan untuk pengembangan aplikasi AR yang dapat membantu pemahaman para pembaca pada suatu teks bacaan berdasarkan pengamatan yang telah dilakukan dalam penelitian ini, yakni 1). Pada sudut pandang estetika dan kemudahaan pengembangan buku atau pun teks maka penggunaan teks langsung sebagai marker tanpa menggunakan marker tambahan lebih baik digunakan. Hanya saja perlu dilakukan penelitian lagi untuk menampilkan objek terhadap bacaan dengan teks yang memiliki konten yang berbeda namun memiliki kemiripan dari segi penulisan. 2). Penggunaan frame untuk tiap teks adalah skenario terbaik, hanya saja perlu dipertimbangkan lebar frame untuk teks tanpa mengurangi kejelasan tulisan dan struktur halaman pada buku pelajaran. 3). Perlu dilakukan penelitian lanjutan mengenai pengembangan objek 3D yang mencerminkan isi 
dari teks, yang belum sempat terlaksanan pada penelitian ini. 4). Perlu dilakukan pengkajian lebih lanjutan untuk pengujian langsung dalam proses belajar mengajar, untuk mengetahui keefektifan pengguaan AR dalam membantu pemahaman dalam sebuah bacaan yang belum terlaksanan pada penelitian ini.

\section{KESIMPULAN}

Berdasarkan atas hasil dari pecobaan maka dapat disimpulkan bahwa,

Pertama: Menampilkan objek 3D menggunakan teknologi AR dengan memanfaatkan teks sebagai penanda (marker) untuk memicu tampilnya objek dapat dilakukan.

Kedua: Aplikasi mampu memindai teks dengan keempat skenario pemposisian marker dengan hasil yang berbeda-beda, dengan hasil terbaik adalah dengan menambahkan frame pada teks sebagai marker dengan nilai modus jarak media terhadap teks hingga kemunculan objek sebesar $7 \mathrm{~cm}$ dengan persentase $55 \%$ dari 40 kali pengujian.

Ketiga: Teks tanpa marker tambahan juga dapat digunakan sebagai pemicu munculnya objek dengan aplikasi AR, dengan hasil yang cukup baik.

\section{DAFTAR RUJUKAN}

Aditia dkk. Implementasi Augmented Reality (AR) Pada Pengenalan Ikan Hias Menggunakan Metode Markerless BerbasisAndroid. handle/123456789/60486,diakses 12 Oktober 2016.

Andria. "Arca, Pengembangan Buku Interaktif Berbasis Augmented Reality dengan smarthone Android". Jurnal Nasional Teknik Elektro dan Teknologi Informasi (JNTETI) $3.2,2014$
Azuma, R T. 2007. A Survey of Augmented Reality. Presense:Teleoperator and Virtual Environment. 2007 : 2 \& 3

Cheng, P dkk. A Review of Using Augmented Reality in Education from 2011 to 2016. Springer: Innovation in Smart Learning, 2016.

Khairnar, K dkk. Furniture Layout Application Based on Marker Detection and Using Augmented Reality, 2015.

Magdalena M. The Field Play Mobile Application: Augmented Reality, Location-Aware Content, And The Creation of An Interactive, DataRich Digital Educational And Research Tool. 168, 2016.

Mauro F. Teaching Mathematics With Augmented Reality.12th International Conference on Technology in Mathematics Teaching, 2015.

Listiyani, Dini. Intel Bikin Saingan Google Glass\&HoloLend 2016/03/04/57/1327554/intel-bikin-saingangoogle-glass-hololens, diakses pada tanggal 14 Oktober 2016.

Jessnor E, dkk. The Use Of Augmented Reality (AR) Among Tertiary Level Students: Perception And Experience.Australian Journal of Sustainable Business and Society 2.1, 2016.

Paivio, Alan \& Mark. A Dual Coding Theoretical Model of Reading.Citeseer, 2004.

Saguni, F. Prinsip-Prinsip Kognitif Pembelajaran Multimedia: Peran Modality dan Contiguity Terhadap Peningkatan Hasil Belajar. INSAN Vol.8 No. 3, 2006.

Suppiah. Peranan Teori Dual Coding Dan Proses Kognisi Dalam Pengajaran Dan Pembelajaran Melalui Kaedah Pedagogi Hermeneutik. Jurnal Pendidikan BITARA UPSI, Vol 6/2013, 2013

Wendra, I W.Tingkat Kekohesifan Abstrak Dalam Artikel Aneka Widya.Jurnal Pendidikan dan Pengajaran IKIP Negeri Singaraja, No $1 \mathrm{TH}$. XXXVI, 2003. 
Ali Idrus., Andreo Yudherta, Pengembangan Augmented Reality Sebagai ...

Wuryani D. Pengembangan Model Pembelajaran Teknologi Pengawetan Makanan dengan Mengintegrasikan Modul Pembelajaran di Akademi Tata Boga Bandung. Jurnal Teknologi Pendidikan, Vol 17, No. 2, Agustus 2015, 2015.

Xiaolin L dkk.Design of Theoretical Model for Smart Learning.Springer:State-of-the-Art and Future Directions of Smart Learning, 2016.

Yudertha, A dkk. The Study of Utilization of Session Initiation Protocolin Mobile Monitoring Abnormal Events Wireless Sensor Network. 2014 6th International Conference on Information Technology and Electrical Engineering, 2014 